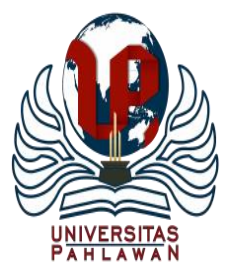

Edukatif : Jurnal Ilmu Pendidikan Volume 3 Nomor 5 Tahun 2021 Halm 2933 - 2943

EDUKATIF: JURNAL ILMU PENDIDIKAN

Research \& Learning in Education

https://edukatif.org/index.php/edukatif/index

\title{
Masalah dan Solusi dalam Pemakaian Konjugasi Kata Kerja Bentuk Masu/Mashita Bahasa Jepang pada Mahasiswa
}

\author{
I Gusti Agung Galuh Wismadewi ${ }^{1 凶}$, Putu Rusanti ${ }^{2}$ \\ Institut Teknologi dan Kesehatan Bali, Indonesia ${ }^{1,2}$ \\ E-mail : galuhhitari@yahoo.com ${ }^{1}$, rusanti.putu@gmail.com ${ }^{2}$
}

\begin{abstract}
Abstrak
Penelitian ini bertujuan untuk mengetahui strategi mengajar yang digunakan oleh dosen Bahasa Jepang saat mengajar mata kuliah Bahasa Jepang Keperawatan pada mahasiswa tingkat II semester III program studi DIV Keperawatan Anastesiologi ITEKES Bali tahun akademik 2019/2020. Penelitian ini dirancang dalam sebuah penelitian deskriptif kualitatif. Konjugasi dalam Bahasa Jepang beraneka ragam, tetapi penulis hanya membahas tentang konjugasi kata kerja bentuk masu/mashita sesuai dengan penelitian yang penulis lakukan. Adapun rumusan masalah pada penelitian ini yaitu strategi apa yang digunakan dalam mengajar Bahasa Jepang Keperawatan Anastesiologi. Apakah alasan dosen menggunakan strategi mengajar metode Information Gap tersebut? Kendala-kendala apa saja yang dihadapi oleh dosen saat mengajar Bahasa Jepang Keperawatan Anastesiologi dengan metode Information Gap? Untuk menjawab pertanyaan penelitian, peneliti memerlukan observation sheet, rekaman saat dosen mengajar dan kuesioner. Adapun luaran target yang direncanakan adalah artikel ilmiah dimuat di jurnal nasional terakreditasi.
\end{abstract}

Kata Kunci: kemampuan, Konjugasi, Kata Kerja.

\begin{abstract}
This study aims to determine the teaching strategies used by Japanese language lecturers when teaching the subject study of Japanese Nursing to the students of level II semester III of the ITEKES Bali D-IV Nursing Anesthesiology study program in the 2019/2020 academic year. This research was designed in a qualitative descriptive study.There are many kinds of conjugation in Japanese, but the writer only discusses verb conjugation in the form of masu/mashita based on the writer research. The problem formulation in this study is what strategies are used in teaching Japanese Language in Nursing Anesthesiology class. What is the reason of the lecturer using the Gap Information method teaching strategy? What are the problems encountered by the lecturer when teaching Japanese Language using Gap Information method in Nursing Anesthesiology class? To answer research questions, researchers need observation sheets, teaching lecturer recording and questionnaire. The planned target output is scientific articles published in accredited national journals.
\end{abstract}

Keywords: Ability, Conjugation, Verb.

Copyright (c) 2021 I Gusti Agung Galuh Wismadewi, Putu Rusanti

$\triangle$ Corresponding author

Email : galuhhitari@yahoo.com

DOI : https://doi.org/10.31004/edukatif.v3i5.1022

ISSN 2656-8063 (Media Cetak)

ISSN 2656-8071 (Media Online) 


\section{Masalah dan Solusi dalam Pemakaian Konjugasi Kata Kerja Bentuk Masu/Mashita Bahasa Jepang pada Mahasiswa - Gusti Agung Galuh Wismadewi, Putu Rusanti \\ DOI: https://doi.org/10.31004/edukatif.v3i5.1022}

\section{PENDAHULUAN}

Bahasa memiliki keterikatan terhadap manusia sebagai penggunanya. Dalam penggunaan bahasa, berbeda maksud dan pikiran penutur, berbeda pula bentuk dan tata bahasa yang digunakan dalam menyampaikan maksud dan pikiran tersebut kepada lawan bicara. Menurut Sari \& Septiani, (2020:149) bahasa adalah sistem lambang bunyi yang arbitrer yang digunakan oleh para anggota kelompok sosial untuk bekerja sama, berkomunikasi, dan mengidentifikasikan diri. Dalam belajar bahasa ada empat aspek keterampilan berbahasa, yaitu keterampilan berbicara, keterampilan menyimak, keterampilan membaca, dan keterampilan menulis. Keempat keterampilan tersebut pada dasarnya merupakan suatu kesatuan yang tidak bisa dipisahkan. Terlihat dalam kenyataannya bahwa dalam memperoleh keterampilan berbahasa, biasanya kita melalui suatu hubungan urutan yang teratur mulai dari kita belajar mendengarkan bahasa kemudian berbicara sesudah itu kita belajar membaca dan menulis.

Pada era globalisasi ketika perkembangan ilmu pengetahuan yang semakin pesat, sudah tidak cukup lagi jika seorang dosen hanya menggunakan metode ceramah dan tanya jawab dalam kegiatan belajarmengajar. Dalam hal ini, sudah selayaknya seorang dosen mampu dan dapat menciptakan suasana belajar yang nyaman dan menyenangkan. Oleh karena itu, pembelajar bahasa Jepang harus tahu tentang perubahan bentuk kata dalam bahasa Jepang, yang biasa disebut konjugasi kata kerja. Peran dosen sangatlah penting dalam menciptakan suasana belajar yang nyaman dan menyenangkan. Peran dosen yang cenderung mendominasi kelas tampaknya dapat dikurangi, dengan memanfaatkan jenis metode yaitu Information gap ke dalam kegiatan belajar mengajar. Dosen yang pada awalnya menggunakan metode ceramah, diskusi dan presentasi pada waktu menjelaskan konjugasi kata kerja masu menjadi mashita mahasiswa banyak mengalami kesulitan dan didak mengerti.

Priyayi et al., (2018) mendeskripsikan tentang permasalahan dalam proses pembelajaran yang buruk dapat dilihat dari indikator yang muncul pada diri siswa, di antaranya:1) perhatian siswa yang kurang dan impulsif, 2) siswa mengumpulkan tugas sebelum tugas selesai, 3) siswa hanya mengharapkan bantuan guru dalam menyelesaikan masalah, 4) tidak ada motivasi untuk mencari tahu, 5) siswa tidak mampu menghilangkan miskonsepsi, 6) siswa hanya memusatkan diri pada perintah guru dan tidak mampu mengaitkan pembelajaran dengan pengetahuan yang dimiliki sebelumnya, 7) tidak ada upaya untuk mengaitkan materi pembelajaran dengan kehidupan sehari-hari. Pembelajaran yang kurang efektif dapat mengarah ke rendahnya hasil belajar siswa. Menurunnya minat belajar mahasiswa dan kurangnya rasa ingin tahu mereka dalam mempelajari bahasa asing, khususnya pelajaran bahasa Jepang pada materi konjugasi kata kerja. Dalam belajar bahasa Jepang dituntut untuk menguasai huruf Jepang, kosakata, dan perubahan kata kerja agar pembelajaran tersebut dapat berjalan lancar. Berdasarkan data mel alui tes pada prodi D-IV Keperawatan Anastesiologi tingakat II semester IV tahun akademik 2019/2020 dan hasil wawancara dengan beberapa mahasiswa di kelas tersebut, diketahui bahwa ada keterbatasan dalam penguasaan mengubah kata kerja bahasa Jepang. Hal ini dikarenakan banyaknya jenis kata kerja dalam bahasa jepang. Untuk meningkatkan kemampuan mahasiswa dalam mengubah jenis kata kerja dalam pembelajaran bahasa Jepang, mahasiswa dituntut agar tekun membaca serta menghafal kosakata kata kerja dalam bahasa Jepang. Akan tetapi, mahasiswa sering merasa bosan dengan pembelajaran yang menggunakan metode ceramah dan tanya jawab. Mahasiswa menjadi acuh tak acuh dan cenderung bermain saat jam pelajaran berlangsung. Selain mengalami kendala dalam penguasaan kosakata, mahasiswa juga masih bergantung pada cara atau strategi dosen dalam mengajar di kelas.

Untuk menangani permasalahan dalam belajar konjugasi dalam bahasa Jepang maka menurut Cahyani \& Setyawati, 2016:153) dalam hasil penelitiannya mengungkapkan bahwa, "dengan adanya proses pemecahan masalah merupakan salah satu elemen penting dalam menggabungkan masalah kehidupan nyata. Saat siswa sedang memecahkan masalah, siswa dihadapkan dengan beberapa tantangan seperti kesulitan dalam 


\section{Masalah dan Solusi dalam Pemakaian Konjugasi Kata Kerja Bentuk Masu/Mashita Bahasa Jepang pada Mahasiswa - Gusti Agung Galuh Wismadewi, Putu Rusanti \\ DOI: https://doi.org/10.31004/edukatif.v3i5.1022}

memahami soal karena masalah yang dihadapi siswa bukanlah masalah yang pernah dihadapi siswa sebelumnya. Ada beberapa faktor yang mendukung kesuksesan pembelajar dalam mempelajari suatu bahasa. Salah satunya adalah metode pembelajaran. Sutikno, (2014: 88) menyatakan bahwa, "metode pembelajaran adalah cara-cara menyajikan materi pelajaran yang dilakukan oleh dosen agar terjadi proses pembelajaran pada diri mahasiswa dalam upaya untuk mencapai tujuan". Metode pembelajaran adalah cara yang digunakan untuk mengimplementasikan rencana yang sudah disusun dalam kegiatan nyata agar tujuan yang telah disusun tercapai secara optimal. Konsep pembelajaran menurut Afandi et al., (2013:15) adalah "suatu proses dimana lingkungan seseorang secara disengaja dikelola untuk memungkinkan ia turut serta dalam tingkah laku tertentu dalam kondisi-kondisi khusus atau menghasilkan respon terhadap situasi tertentu, pembelajaran merupakan subset khusus dari pendidikan". Menurut Fay, (1967) faktor yang mempengaruhi keberhasilan siswa dalam penguasaan bahasa ada dua faktor; personal factors dan general factors. Personal Factors yaitu; kedinamisan kelompok, sikap terhadap guru, dan materi pengajaran. Sedangkan General Factors yaitu;usia, kecerdasan, kesadaran, motivasi, dan tabiat.

Penelitian yang dilakukan dapat dibandingkan dengan beberapa penelitian lain yang ruang lingkupnya masih ada keterkaitan. Sebuah penelitian (Riska, 2015) yang berjudul Analisis Kesalahan Siswa Dalam Mengubah Masukei Menjadi Takei Di Sma Kesatrian 1 Dari hasil penelitian ini terdapat kesalahan siswa kelas XII MIPA 3 di SMA Kesatrian 1 Semarang dalam menggunakan kata kerja bentuk - ta, yaitu kesalahan siswa dalam mengubah kata kerja golongan I, II, III bentuk -masu ke kata kerja golongan I, II, III bentuk -ta, dan kata kerja golongan I, II, III bentuk -ta menjadi kata kerja golongan I, II, III bentuk - masu. Faktor penyebab siswa mengalami kesalahan dalam menggunakan kata kerja bentuk - ta yaitu Siswa sering mengalami kesulitan dalam mempelajari pola kalimat yang berhubungan dengan kata kerja bentuk ta dan sering kesulitan dalam mengubah kata kerja bentuk ta. Siswa juga jarang mencatat poin-poin penting yang berkaitan dengan pola kalimat dan perubahan kata kerja bentuk ta. Sedangkan penelitian yang dilakukan dalam kegiatan ini adalah metode yang digunakan untuk menanggulangi permasalahn dalam perubahan kata kerja yaitu dengan kegiatan Information Gap untuk dapat meningkatkan kemampuan siswa dalam hal merubah kata kerja. Lingkungan belajar hendaknya dikelola dengan baik karena pembelajaran memiliki peranan penting dalam pendidikan. Metode pembelajaran salah satu kompenen penting dalam proses belajar mengajar yang perlu dikuasai oleh dosen. Dalam hal ini, metode pembelajaran bahasa Jepang harus dikemas dalam bentuk pembelajaran yang menarik sehingga metode pembelajaran perlu didukung dengan media pembelajaran yang tepat juga. Penelitian yang dilakukan M. I. Sari, (2020) Penelitian ini diadakan di SMP-IT Insan Cendekia Boarding School Payakumbuh, Jl. RA. Kartini Kelurahan Padang Kaduduk Kecamatan Payakumbuh Utara Kota Payakumbuh. Penelitian dilaksanakan di kelas IX.1, mulai dari tanggal 1 Oktober 2018 sampai tanggal 9 November 2018. Penelitian dilaksanakan sebanyak 2 siklus. Setiap siklus terdiri dari 4 langkah, yakni perencanaan, tindakan, observasi dan refleksi. Hasilnya jelas bahwa penerapan Information Gab Activities ini memberikan dampak yang bagus terhadap kemampuan berbicara Setelah Information Gab Activities ini dilaksanakan selama 2 siklus, dapat disimpulkan bahwa Information Gab Activities sangat membantu dalam berbicara siswa. Interaksi siswa dalam kelas sangat berkembang. Penerapan IGA (Information Gap Activities) dapat menstimulasi dan memotivasi siswa dalam belajar sehingga mereka tertarik untuk berbahasa. Mereka memiliki peluang yang banyak untuk berbicara. Siswa bisa meningkatkan kolaborasi dalam belajar, dan melatih siswa untuk mengembangkan skill berbicaranya. Siswa memberikan respon positif terhadap penerapan Information Gab Activities ini dalam pembelajarannya.

Riska, (2015:2) Penggunaan media yang tepat oleh guru akan mempengaruhi hasil belajar siswa yang bersangkutan. Penggunaan media pembelajaran tidak hanya berguna untuk membantu guru dalam penyampaian materi tetapi juga mempunyai tujuan untuk memudahkan siswa dalam menerima materi yang disampaikan dan penggunaan media pembelajaran dalam proses belajar-mengajar di dalam kelas dapat dilaksanakan melalui beberapa langkah yaitu sebagai berikut: (1) Guru terlebih dahulu mengidentifikasi 


\section{Masalah dan Solusi dalam Pemakaian Konjugasi Kata Kerja Bentuk Masu/Mashita Bahasa Jepang pada Mahasiswa - Gusti Agung Galuh Wismadewi, Putu Rusanti \\ DOI: https://doi.org/10.31004/edukatif.v3i5.1022}

pokok-pokok isi pelajaran yang akan disampaikan; (2) Guru hendaknya memilih teknik atau metode yang hendak ia gunakan dalam menyampaikan pelajaran kepada anak-anak; (3) Guru harus memeriksa apakah media yang akan ia gunakan dalam keadaan baik dan dapat berfungsi dengan benar. Media pembelajaran ini dilakukan bukan hanya sekadar hal biasa, melainkan penggunaan media pembelajaran oleh pendidik dalam proses pembelajaran di kelas yang sesuai dan tepat dengan karakteristik mahasiswa, maka proses pembelajaran menjadi lebih menarik dan membangkitkan motivasi mahasiswa dalam belajar. Menggunakan media pengajaran yang tepat dan metode yang relevan untuk mengatur dan menyajikan informasi juga dapat meningkatkan efisiensi proses belajar mandiri dan meningkatkan minat mahasiswa untuk belajar Hade \& Aswirna, (2019: 741). Oleh karena itu, media pembelajaran menjadi suatu hal yang penting dan harus dikuasai oleh setiap pendidik professional. Adapun batasan media adalah segala sesuatu yang dapat digunakan untuk menyalurkan pesan dari pengirim pesan ke penerima pesan sehingga dapat merangsang pikiran, perasaan, perhatian, dan minat serta rangsangan ingatan mahasiswa. Pemilihan dan pemanfaatan media pembelajaran sebagai alat bantu harus sesuai dengan kebutuhan pembelajar. Yulianti Tri, (2013:2) Media apabila dipahami secara garis besar adalah manusia, materi, atau kejadian yang membangun kondisi yang membuat siswa mampu memperoleh pengetahuan, keterampilan, atau sikap. Penggunaan media yang tepat oleh guru akan mempengaruhi hasil belajar siswa yang bersangkutan. Penggunaan media pembelajaran tidak hanya berguna untuk membantu guru dalam penyampaian materi tetapi juga mempunyai tujuan untuk memudahkan siswa dalam menerima materi yang disampaikan. Savira \& Suharsono, (2013) Dengan melihat permasalahan yang dihadapi mahasiswa prodi D-IV Keperwatan Anastesiologi, maka salah satu metode pembelajaran yang dapat digunakan dalam pembelajaran bahasa Jepang adalah dengan menggunakan jenis kegiatan information gap yaitu latihan percakapan atau tanya jawab dengan menggunakan kartu gambar atau kartu informasi. Pada kegiatan ini, mahasiswa lebih mudah menerima materi yang diajarkan, terutama materi konjugasi kata kerja bentuk masu/mashita dalam kegiatan sehari-hari. Selama ini, kemampuan mahasiswa khususnya dalam konjugasi kata kerja masih rendah dan perlu ditingkatkan. Untuk mencapai tujuan tersebut diperlukan strategi pembelajaran yang dapat mendukung tercapainya tujuan tersebut. Salah satunya adalah dengan menggunakan jenis metode kegiatan informaton gap.

Menurut Sutedi, (2019: 47-55) kata yang mengalami perubahan bentuk dalam bahasa Jepang disebut yougen, sedangkan kata yang tidak mengalami perubahan bentuk disebut taigen. Yougen terdiri dari doushi 'verba', jodoushi 'kopula', dan keiyoshi 'adjektiva'. Adjektiva dalam bahasa Jepang ada dua macam yaitu yang berakhiran huruf atau bunyi i (い) keiyoushi atau i keiyoushi dan yang berakhiran huruf na (な) yang disebut dengan keiyoudoushi atau na keiyoushi.perubahan bentuk verba dalam bahasa Jepang jisho-kei. Dalam Penelitian ini akan dijelaskan tentang pengertian doushi (kata kerja) dan jenis-jenis kata kerja dalam bahasa Jepang. Kemudian dijelaskan juga mengenai hojo doushi (kata kerja penunjang), beserta konjugasi bentuk te. Dalam bahasa Jepang, kata yang mengalami perubahan bentuk disebut (用言'yougen'), sedangkan kata yang tidak mengalami perubahan bentuk disebut ( 体言taigen). Yougen terdiri dari

（動詞‘どうし）、（じどうし’自動詞’）dan ( 形容詞“keiyoshi) atau (い形容詞‘I keiyoushi’), dan yang berakhiran huruf (な’na') yang disebut dengan 形容動詞“keiyodoushi) atau (名形容詞'NA- keiyoushi). Tetapi yang mengalami perubahan bentuk hanya adjektiva I saja. Kata kerja dalam bahasa Jepang disebut dengan doushi. Biasanya kata kerja selalu terletak pada bagian akhir kalimat dan memiliki berbagai macam jenis, seperti jidoushi, tadoushi, dan hojo doushi. Dalam penggunaanya, kata kerja mengalami perubahan bentuk yang dalam bahasa Jepang disebut dengan katsuyou. Ada enam jenis katsuyou yang terdapat dalam kata kerja. Dalam penelitian ini, akan dijelaskan mengenai perubahan bentuk masu/ mashita yang nanti akan mempermudah kita untuk memahami penggunaan kata kerja tersebut. Perubahan ini digolongkan ke dalam tiga kelompok. Jenis- jenis kata kerja antara lain: Jidoushi atau kata kerja aktif Jika subjek aktif melakukan aktivitas, yang diikuti dengan kata bantu ga, kata kerja ini disebut kata kerja aktif atau jidoushi. Tadoushi atau kata keja pasif. Jika orang atau benda menjadi objek suatu aktivitas atau pekerjaan yang diikuti dengan kata 


\section{Masalah dan Solusi dalam Pemakaian Konjugasi Kata Kerja Bentuk Masu/Mashita Bahasa Jepang pada Mahasiswa - Gusti Agung Galuh Wismadewi, Putu Rusanti \\ DOI: https://doi.org/10.31004/edukatif.v3i5.1022}

bantu wo, kata kerja ini disebut kata kerja pasif atau Tadoushi.Hojo doushi, yaitu kata kerja formalitas. Contoh; aru, miru, iru, kuru, iku, shimasu, oku, dan yaru. Dalam bahasa Jepang, kata yang mengalami perubahan bentuk disebut (用言'yougen'), sedangkan kata yang tidak mengalami perubahan bentuk disebut ( 体言taigen). Yougen terdiri dari (動詞‘どうし)、（じどうし’自動詞’）dan（形容詞“keiyoshi） atau (い形容詞'I keiyoushi'), dan yang berakhiran huruf (な’na’) yang disebut dengan 形容動詞“keiyodoushi) atau (名形容詞’NA- keiyoushi). Sedangkan menurut (Rosliana, 2014:51) verba berkonjugasi -rareru pada verba pasif dengan bentuk verba yang dimiliki oleh bentuk potensial (kanoukei) dan bentuk hormat (keigo) pada bahasa. Verba dalam bahasa Jepang berada pada akhir klausa atau akhir kalimat. Verba (doushi) yaitu kata yang dapat berfungsi menjadi predikat dalam suatu kalimat, mengalami perubahan bentuk atau katsuyou dan dapat berdiri sendiri. Perubahan Bentuk Verba dalam bahasa Jepang dapat digolongkan menjadi tiga kelompok yaitu golongan I, golongan II dan golongan III (Jannah et al., 2019:79). Lusiana Evi, ( 2017:162) materi yang diambil dalam penelitian yaitu tentang perubahahan kata kerja lampau dalam materi nani o shimashitaka (なにをしましたか), pada materi tersebut diperlihatkan tentang gambar kegiatan lampau.

Institut Teknologi dan Kesehatan Bali (ITEKES Bali) yang didirikan di pusat kota Denpasar yang berlokasi di Renon merupakan kampus kesehatan yang menyalurkan tenaga kerja ke luar Negeri seperti Jepang dan Jerman. Kampus kesehatan ini disediakan pelatihan untuk kebutuhan mahasiswa di lingkungan sekitar dengan tujuan agar mahasiswa dapat mengembangkan keterampilan berbahasa, diantaranya adalah menulis dan berbicara melakukan percakapan dalam bahasa Jepang. Dengan melatih sejak dini diharapkan dapat mengembangkan keterampilan tersebut sehingga dapat mencetak mahasiswa yang terampil dalam berbahasa Jepang untuk bekal bekerja nanti. Kurangnya minat membaca mahasiswa sehingga mempengaruhi produktivitas menulis dan berbicara dapat dikatakan sangat kurang. Sudah selayaknya di kampus ini diadakan pelatihan. Kegiatan ini sangat baik dilakukan di lingkungan tersebut. Selain itu juga dapat menambah wawasan mahasiswa, manfaat lain yang bisa diambil dalam kegiatan ini yaitu dapat meningkatkan keterampilan berbahasa mereka. Keterampilan berbahasa merupakan sesuatu yang penting untuk dikuasai setiap orang. Dalam suatu masyarakat, setiap orang saling berhubungan dengan orang lain dengan cara berkomunikasi. Tidak dapat dipungkiri bahwa keterampilan berbahasa ialah salah satu unsur penting yang menentukan kesuksesan mereka dalam berkomunikasi.

Mata kuliah Bahasa Jepang dipelajari pada semester 4 yang sebelumnya mereka belum pernah pelajari di bangku SMA. Dalam waktu satu semester merupakan waktu yang sangat singkat untuk belajar bahasa apalagi itu bahasa aing yang jarang kita dengar dan gunakan. Maka peneliti melakukan pelatihan untuk memantapkan lagi bahasa Jepang mahasiswa di Itekes Bali khususnya pada program studi D-IV Keperaatan anastesiologi. Pelatihan ini fokus pada latihan menulis dan berbicara tentang perubahan kata kerjadalam bahasa Jepang. Karena dalam bahasa Jepang banyak sekali ada perubahan kata kerja tergantung waktu dan konteks kalimat. Yang akan dibahas disini adalah tentang perubahan kata kerja bentuk biasa dan lampau yaitu masu dan mashita. Dalam materi ini seringkali mahasiswa bingung dan keliru dalam merlakukan konjugasi atau mengubah kata kerja tersebut, maka dari itu peneliti menggunakan kegiatan Information Gap dalam pengajaran materi ini untuk mudah dimengerti mahasiswa. Sebelum melakukan pelatihan pengajar hanya menggunakan metode ceramah, diskusi dan presentasi yang sulit dimengerti oleh mahasiswa karena jarang dipraktekkan.

Dalam mengajar bahasa Jepang terdapat empat aspek keterampilan berbahasa yaitu berbicara, mendengarkan, membaca dan menulis. Aspek berbicara jenis kegiatannya antara lain: Interview, Information Gap, Role Play dan Game. Sedangkan kegiatan mendengarkan ada mencocokkan gambar, Dikte dan Game. Untuk kegiatan keterampilan membaca mencocokkan gambar, menulis dan keterampilan menulis jenis kegiatannya adalah karangan, balasan surat, dan latihan kalimat. Dalam penelitian ini peneliti menggunakan jenis kegiatan Information Gap. Lusiana Evi, (2009:viii) Infometion Gap adalah kegiatan mahasiswa 


\section{Masalah dan Solusi dalam Pemakaian Konjugasi Kata Kerja Bentuk Masu/Mashita Bahasa Jepang pada Mahasiswa - Gusti Agung Galuh Wismadewi, Putu Rusanti \\ DOI: https://doi.org/10.31004/edukatif.v3i5.1022}

melakukan percakapan atau tanya jawab dengan menggunakan kartu gambar atau kartu informasi dengan saling bertukar informasi. Berdasarkan uraian dalam latar belakang, identifikasi masalah serta pembatasan masalah, maka tujuan yang ingin dicapai dalam penelitian ini adalah untuk mengetahui kemampuan mahasiswa dalam konjugasi kata kerja bentuk masu/mashita bahasa Jepang pada prodi D-IV Keperwatan Anastesiologi ITEKES Bali tahun akademik 2019/2020 sebelum menggunakan metode information gap dalam proses pembelajaran, yang sebelumnya menggunakan metode ceramah, diskusi dan presentasi. Selain itu untuk mengetahui manfaat kegiatan information gap dalam pendidikan bahasa Jepang terutama dalam konjugasi kata kerja dalam bahasa Jepang pada mahasiswa prodi D-IV Keperwatan Anastesiologi ITEKES Bali tahun akademik 2019/2020 dalam proses pembelajaran.

\section{METODE PENELITIAN}

Penelitian ini menggunakan desain deskriptif dengan menggunakan pendekatan kualitatif sehingga data yang dihasilkan adalah berupa kata-kata dan kalimat sesuai dengan kondisi yang didapat dari hasil open-ended questionnaire, interview, dan observasi. Menurut Shidiq \& Choiri, (2019:5) Secara garis besar pengertian penelitian kualitatif adalah penelitian yang bertujuan memahami fenomena yang dialami oleh subyek penelitian. Misalnya perilaku, persepsi, motivasi, tindakan, dan sebagainya, secara holistik dengan cara deskriptif dalam suatu konteks khusus yang alami tanpa ada campur tangan manusia dan dengan memanfaatkan secara optimal. Konsep dasar penelitian kualitatif istilah-istilah penelitian kualitatif merupakan penelitian untuk mengeksplorasi dan memahami makna yang oleh sejumlah individu atau kelompok orang dianggap berasal dari masalah social atau kemanusiaan Shidiq \& Choiri, (2019:2) menjelaskan bahwa proses penelitian kualitatif ini melibatkan upaya-upaya penting, seperti mengajukan pertanyaan- pertanyaan dan prosedur-prosedur, mengumpulkan data 3 yang spesifik dari para partisipan, menganalisis data secara induktif mulai dari tema-tema yang khusus ke tema-tema umum, dan menafsirkan makna data.

Subjek dari penelitian ini adalah mahasiswa di kampus ITEKES Bali, khususnya mahasiswa Prodi D-IV Anastesiologi tingkat II yang sedang mendapatkan mata kuliah Bahasa Jepang. Penelitian ini dilaksanakan selama 3 kali pertemuan. Penelitian dilaksanakan di kampus II ITEKES Bali, Jalan Tukad Balian No. 180 Renon-Denpasar. Jumlah mahasiswa Tingkat II yang terdiri dari dua kelas yaitu kelas A berjumlah 83 orang dan kelas B berjumlah 82 orang. Pelaksanaan kegiatan ini dilakukan mulai bulan Desember 2019 sampai Mei 2020. Banyak cara yang bisa ditempuh untuk mengembangkan keterampilan berbahasa. Salah satunya yaitu dengan kegiatan berbicara (kaiwa) dengan kegiatan Information Gap. Kegiatan pelatihan ini bertujuan untuk mengembangkan keterampilan berbicara mahasiswa. Dalam kegiatan ini narasumber memandu mahasiswa dalam melakukan pengubahan kata kerja masu dan mashita dalam bahasa Jepang untuk kegiatan berbicara. Mahasiswa diberi waktu untuk mengerjakan latihan soal. Setelah kegiatan membaca selesai, mereka diminta menceritakan kembali isi teks yang telah mereka kerjakan. Narasumber meninjau sejauh mana kemampuan mereka dalam mengubah kata kerja bentuk masu dan mashita tersebut.

Instrumen pertama yang digunakan adalah kuisioner yang diberikan kepada mahasiswa yang sedang mendapatkan mata kuliah Bahasa Jepang. Kuisioner yang digunakan menggunakan untuk mencari tahu lebih dalam mengenai tingkat kemampuan responden sehingga mendapatkan jawaban yang di luar dugaan. Instrument yang kedua adalah daftar wawancara terstruktur untuk mahasiswa. Instrument yang ketiga adalah lembar observasi yang digunakan untuk mencatat hasil observasi di kelas. Pengumpulan data akan dikumpulkan melalui metode kuisioner, observasi, dan wawancara. Kuisioner akan diberikan kepada mahasiswa secara acak digunakan untuk mengetahui masalah yang dihadapi oleh mahasiswa dalam mengerjakan soal konjugasi kata kerja. Observasi juga akan dilakukan di kelas. Selain itu, wawancara terstruktur dilakukan dengan mewawancarai beberapa mahasiswa. Berdasarkan metode pelaksanaan, penulis membuat langkah-langkah pelaksanaan kegiatan penelitian ini seperti berikut Berdasarkan hasil wawancara 


\section{Masalah dan Solusi dalam Pemakaian Konjugasi Kata Kerja Bentuk Masu/Mashita Bahasa Jepang pada Mahasiswa - Gusti Agung Galuh Wismadewi, Putu Rusanti \\ DOI: https://doi.org/10.31004/edukatif.v3i5.1022}

yang telah dilaksanakan dengan mahasiswa, teridentifikasi beberapa masalah yang ada dalam pembelajaran, yaitu (1) dalam kegiatan belajar-mengajar masih berpusat pada dosen, (2) kurangnya keberanian mahasiswa untuk mengemukakan pendapat pada saat dosen menjelaskan atau memberikan pertanyaan.

Berdasarkan permasalahan tersebut, peneliti mencoba mengemukakan solusi yaitu paradigma pembelajaran baru yang sesuai dengan tuntutan kurikulum. Adapun paradigma yang dimaksud adalah menerapkan teknik information gap. Sebagai tindak lanjut atau solusi yang ditawarkan tersebut untuk memecahkan masalah yang dihadapi dosen dalam pembelajaran bahasa Jepang pada Prodi D-IV Anastesiologi tingkat II, maka penelitian ini dilakukan dengan beberapa siklus. Setiap siklus terdiri atas tahapan-tahapan yaitu perencanaan, pelaksanaan tindakan, observasi/evaluasi, dan refleksi. Berdasarkan hasil refleksi awal, maka pada siklus I ini dirancang kegiatan seperti mengkaji RPS, Menyusun rencana pembelajaran sebagai pedoman untuk melaksanakan pembelajaran sesuai dengan teknik information gap, mempersiapkan media pembelajaran dan mempersiapkan tes hasil belajar. Berikutnya kegiatan yang dilakukan pada tahap ini adalah melaksanakan pembelajaran pada prodi D-IV Anastesiologi tingkat II dalam satu kali pertemuan sesuai dengan rencana pembelajaran. Pelaksanaan tindakan itu menggunakan teknik information gap yang telah disusun dengan bantuan media gambar dan kartu kosakata pengajaran dalam meningkatkan stimulus mahasiswa.

\section{HASIL DAN PEMBAHASAN PENELITIAN}

Pengamatan terhadap objek kegiatan penelitian ini, masih dapat dikatakan belum terfasilitasi dengan baik. Dengan keterbatasan materi pembelajaran, peneliti selaku tutor mencoba memberikan perhatian lebih terhadap mahasiswa dalam mata pelajaran bahasa Jepang, yaitu dalam materi merubah kata kerja. Fokus perhatian ini bertujuan untuk mengembangkan keterampilan berbahasa yang mereka miliki. Media yang digunakan adalah media gambar yang berhubungan dengan kegiatan Information Gap. Proses awal kegiatan penelitian ini dilakukan dengan melakukan analisis situasi di kampus II ITEKES Bali, Jalan Tukad Balian No. 180 Renon-Denpasar terlebih dahulu. Hal ini dimaksudkan untuk mengetahui keadaan yang diperlukan dalam kegiatan ini sesuai dengan tujuan, yaitu Untuk mengetahui kemampuan mahasiswa dalam konjugasi kata kerja bentuk masu/mashita bahasa Jepang pada prodi D-IV Keperwatan Anastesiologi ITEKES Bali tahun akademik 2019/2020 sebelum menggunakan metode information gap dalam proses pembelajaran. Yang sebelumnya menggunakan metode ceramah, diskusi dan presentasi dan untuk mengetahui manfaat kegiatan information gap dalam pendidikan bahasa Jepang terutama dalam konjugasi kata kerja dalam bahasa Jepang pada mahasiswa prodi D-IV Keperwatan Anastesiologi ITEKES Bali tahun akademik 2019/2020 dalam proses pembelajaran.

Sampel dalam penelitian ini adalah mahasiswa prodi D-IV Keperawatan Anastesiologi tingkat II yang mendapatkan mata kuliah Bahasa Jepang. Dalam mata kuliah Bahasa Jepang, mahasiswa diajarkan untuk menguasai empat kemampuan berbahasa yaitu berbicara, mendengarkan, membaca, dan menulis data dari 165 mahasiswa, kurangnya pengetahuan kosa kata sebanyak 58, mahasiswa yang mengalami kesulitan dalam konjugasi ada 54 orang. Dan mahasiswa yang merespon tidak mengalami kesulitan dalam konjugasi ada 53 orang. Hal tersebut dapat dilihat pada gambar 1 di bawah ini. 


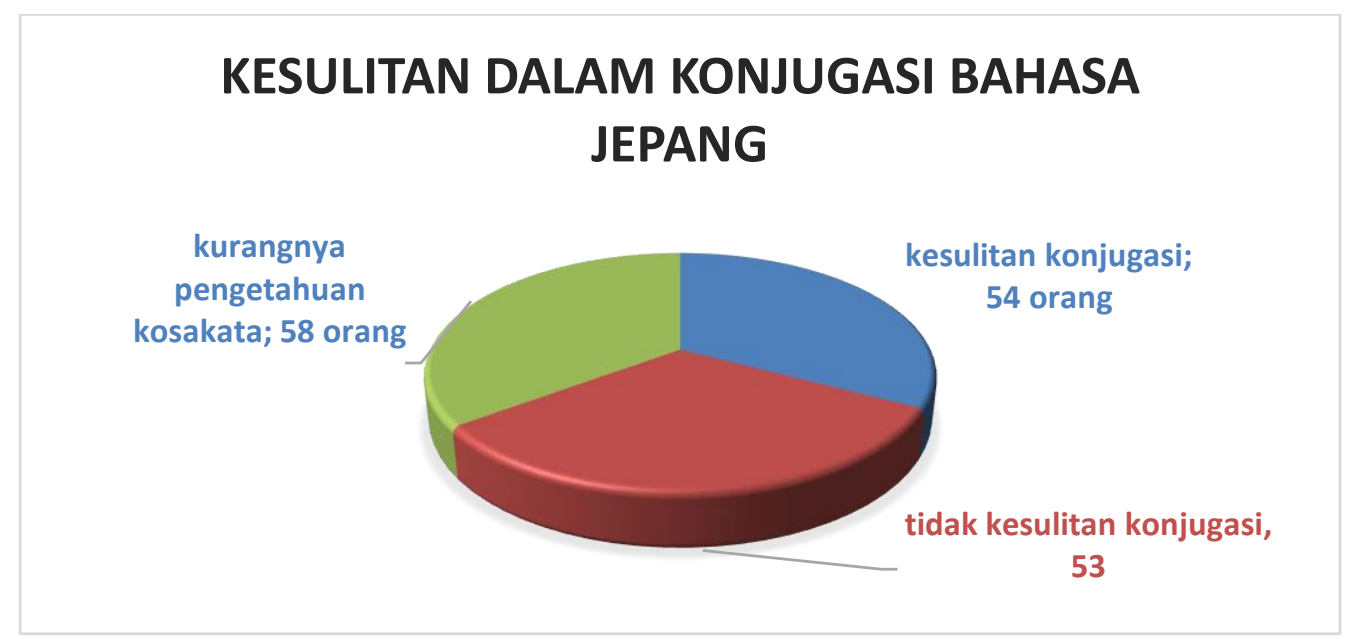

Gambar 1 Kesulitan Mahasiswa dalam konjugasi Bahasa Jepang

Pada tabel hasil angket di atas dengan jumlah 165 mahasiswa yaitu 54 orang menunjukkan kecenderungan mengalami kesulitan dalam pembelajaran konjugasi bahasa Jepang. Mahasiswa juga banyak menyampaikan bahwa kemampuan dalam pemakaian konjugasi kata kerja bahasa Jepang pada tahapan pertama masih kurang karena metode ceramah diberikan pada proses pembelajaran. Begitu pula, dapat dilihat pada minat mahasiswa dalam penggunaan metode information gap untuk peningkatan kemampuan pemakaian konjugasi kata kerja. Dengan demikian, pembelajaran menulis karangan deskripsi bahasa Jepang dengan menerapkan metode information gap dipandang perlu untuk diterapkan. Selain itu, masalah yang dihadapi oleh mahasiswa ketika belajar Bahasa Jepang adalah kurangnya motivasi belajar Bahasa Jepang. Motivasi ini dapat berasal dari dalam diri dan dari lingkungan. Mahasiswa merasa mata kuliah Bahasa Jepang sulit untuk dipelajari sehingga mereka tidak berminat untuk mempelajari dengan serius. Hal ini akan berdampak pada kemauan untuk belajar dan menghapal kosakata yang berhubungan dengan keperawatan. Hal ini dapat dilihat pada gambar 2 di bawah ini. Sebagian besar mahasiswa menyatakan sering kurang motivasi dalam belajar Bahasa Jepang.

\section{MOTIVASI BELAJAR BAHASA JEPANG}

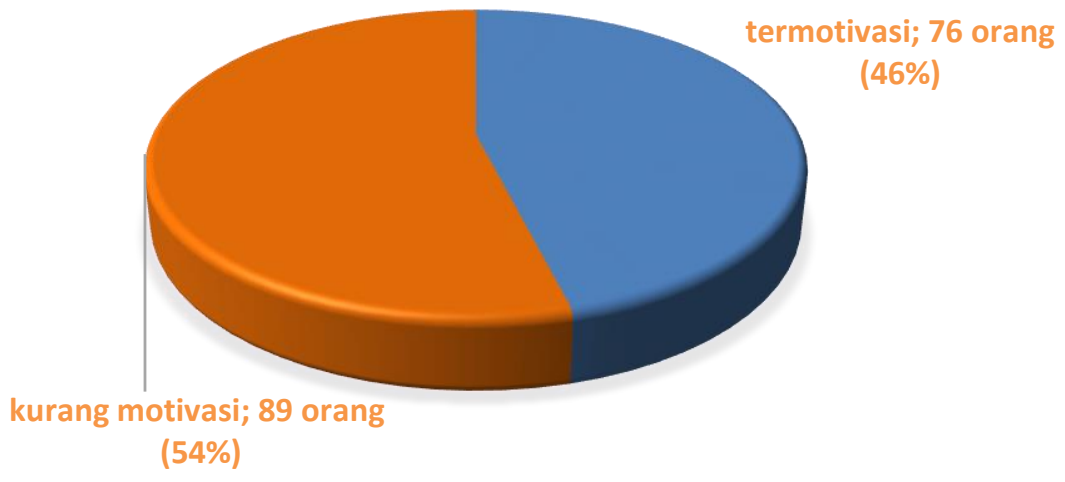

Gambar 2 Masalah dalam belajar Bahasa Jepang adalah kurang motivasi

Pada tabel hasil angket di atas dengan jumlah 165 mahasiswa, 89 mahasiswa termotivasi belajar bahasa Jepang, sedangkan hanya 78 responden yang mengalami kurangnya motivasi dalam belajar bahasa Jepang. Motivasi ini dapat berasal dari dalam diri dan dari lingkungan. Hal ini menunjukkan bahwa hampir sebagian besar mahasiswa mengalami masalah pada kurangnya motivasi belajar. Untuk mengatasi masalah yang dihadapi oleh mahasiswa Prodi D-IV Keperawatan Anastesiologi beberapa strategi perlu dilakukan oleh dosen pengajar. Wawancara dilakukan pada dosen pengajar Bahasa Jepang. Beberapa strategi yang diterapkan oleh 


\section{Masalah dan Solusi dalam Pemakaian Konjugasi Kata Kerja Bentuk Masu/Mashita Bahasa Jepang pada Mahasiswa - Gusti Agung Galuh Wismadewi, Putu Rusanti \\ DOI: https://doi.org/10.31004/edukatif.v3i5.1022}

dosen pengajar antara lain mengajar dengan metode Information Gap. Dalam belajar Bahasa kita memiliki empat ketrampilan yaitu, membaca, menulis, berbicara dan mendengarkan. Pada kegiatan ini digunakan kegiatan berbicara yaitu information gap. Dosen menjelaskan materi tentang kalimat biasa dan kalimat lampau. Mahasiswa menggunak kegiatan ini untuk latihan atau bertukar informasi dengan temannya. Dan menerapkan games dalam pembelajaran. Proses pembelajaran yang inovatif juga sangat diperlukan dalam pengajaran. Hal ini agar mahasiswa tidak bosan dengan metode pembelajaran yang monoton. Beberapa games dapat membantu meningkatkan minat mahasiswa untuk belajar Bahasa Jepang. Namun, perlu diperhitungkan pemilihan games yang tepat untuk mahasiswa. Dosen pengajar Bahasa Jepang biasanya menerapkan games untuk sekedar ice breaking pada awal pembelajaran. Hal ini bertujuan untuk menarik perhatian mahasiswa dalam belajar Bahasa Jepang.

Mata kuliah Bahasa Jepang adalah salah satu mata kuliah wajib yang diperoleh oleh mahasiswa keperawatan Anastesiologi tingkat II. Dalam belajar Bahasa Jepang banyak mahasiswa yang masih masih mengalami kesulitan. Dalam belajar Bahasa, mahasiswa diharapkan menguasai 4 kemampuan berbahasa yaitu berbicara, mendengarkan, membaca, dan menulis. Berdasarkan hasil kuesioner, masalah yang dialami oleh mahasiswa dalam hal skill konjugasi adalah merubah kata kerja dari bentuk biasa ke bentuk lampau. Karena dalam belajar Bahasa Jepang cukup banyak akan mempelajari perubahan kata kerja. Merubah kata kerja merupakan materi yang paling sulit dipelajari. Hal ini dikarenakan mahasiswa belum mempunyai pengetahuan sebelumnya (background knowledge) mengenai kosakata yang berhubungan dengan kata kerja. Dilihat dari data mahasiswa yang sebagian besar mengalami kesulitan dalam merubah kata kerja dan kurangnya motivasi belajar bahasa Jepang. Selain itu, kurangnya pengetahuan kosakata yang dimiliki mahasiswa juga mempengaruhi kemampuan memahami suatu wacana, dan juga yang dihadapi mahasiswa dalam pemakaian konjugasi kata kerja bentuk masu/mashita. Pada penilaian aspek isi gagasan dinilai berdasarkan dua aspek penilaian, yaitu isi gagasan sesuai dengan tema dan pengembangan ide yang dituangkan tuntas dengan adanya kalimat yang menggunakan konjugasi kata kerja. Selanjutnya, penilaian pada struktur bahasa, yaitu mengikuti tata bahasa kalimat bahasa Jepang, yakni S-K-O-P (Subjek Keterangan Objek Predikat) dan penggunaan pola kalimat kata kerja dengan tepat.

Sebuah Penelitian yang dilakukan oleh yusuf A, (2012) berjudul Efektivitas Model Pembelajaran Bahasa Jepang Di SMA Negeri Cisarua Dengan menggunakan Teknik Information Gap. Penelitian ini samasama mengajarkan Bahasa Jepang dan menggunakan teknik Information Gap, yang hanya membedakan adalah tempat melakukan penelitian yaitu tingkat SMA dan perguruan tinggi dan subjek penelitiannya siswa SMA Negeri Cisarua dan mahasiswa ITEKES Bali. Hasil dari penelitian ini sama-sama dapat meningkatkan keterampilan berbicara. Di SMA Cisarua peneliti hanya mengambil ketrampilan berbicara sedangkan di ITEKES Bali peneliti mengambil keterampilan menulis dan berbicara. Selanjutnya penelitian Lailatul, (2017) berjudul Hasil Belajar Berbicara Bahasa Jerman Melalui Penerapan Teknik Iga (Information Gap Activities) Siswa Kelas XI IPS -2 SMA Negeri 3 Kediri. Penelitian ini sama-sama menggunakan teknik Information Gap, yang membedakan adalah tempat penelitian di SMA Negeri 3 Kediri dan IITEKES Bali, subjek penelitian yang dilakukan Jamila adalah siswa kelas XI IPS 2 SMA Negeri 3 Kediri dan subjek peneliti sendiri adalah Mahasiswa prodi D-IV keperawatan Anastesiologi. Serta mata pelajaran yang berbeda antara Bahasa Jerman dan Bahasa Jepang. Sedangkan tujuan dari penelitian Jamila adalah Mendeskripsikan hasil belajar berbicara bahasa jerman setelah melalui penerapan Teknik IGA (Information Gap Activities) Siswa Kelas XI IPS-2 SMA Negeri 3 Kediri. Sedangkan peneliti sendiri adalah Untuk mengetahui kemampuan mahasiswa dalam konjugasi kata kerja bentuk masu/mashita bahasa Jepang pada prodi D-IV Keperwatan Anastesiologi ITEKES Bali tahun akademik 2019/2020 sebelum menggunakan metode information gap dalam proses pembelajaran. Yang sebelumnya menggunakan metode ceramah, diskusi dan presentasi dan untuk mengetahui manfaat kegiatan information gap dalam pendidikan bahasa Jepang terutama dalam konjugasi kata kerja dalam bahasa 


\section{Masalah dan Solusi dalam Pemakaian Konjugasi Kata Kerja Bentuk Masu/Mashita Bahasa Jepang pada Mahasiswa - Gusti Agung Galuh Wismadewi, Putu Rusanti \\ DOI: https://doi.org/10.31004/edukatif.v3i5.1022}

Jepang pada mahasiswa prodi D-IV Keperawatan Anastesiologi ITEKES Bali tahun akademik 2019/2020 dalam proses pembelajaran.

Penelitian yang dilakukan oleh (Apriyanti Nia Dwi, 2015:ix) dengan judul Analisis Kesalahan Dalam Penggunaan Unsur Keizoku Doushi Dengan Shunkan Doushi Pada Kalimat. Berdasarkan hasil studi pendahuluan berupa tes terhadap 20 mahasiswa semester IV angkatan 2013 Prodi Pendidikan Bahasa Jepang, menyatakan bahwa prosentase kesalahan penggunaan keizoku doushi dan shunkan doushi tergolong cukup tinggi yaitu sebesar $61,7 \%$. Persamaan penelitian ini adalah dilakukan pada tingkat perguruan tinggi. Perbedaan kedua penelitian ini adalah Hasil studi pendahuluan tersebut menunjukkan bahwa masih ada mahasiswa yang tidak menguasai unsur keizoku doushi dan shunkan doushi, dan cenderung salah dalam menggunakan unsur keizoku doushi dan shunkan doushi. Sedangkan pada penelitian yang dilakukan itu permasalahannya pada perubahan kata kerja. Dalam penelitian Risyandi et al, (2017) yang berjudul Penerapan Penggunaan Media Anime Terhadap Peningkatan Kemampuan Menulis Kalimat Yang Mengandung Kata Kerja Bahasa Jepang. Sampel dari penelitian ini adalah mahasiswa tingkat 2 jurusan pendidikan bahasa jepang universitas pendidikan Indonesia tahun 2017, sejumlah 5 orang. Persamaan dari penelitian ini sama-sama dilakukan pada tingkat perguruan tinggi dan mengambil materi yang sama yaitu tentang kata kerja. Perbedaan penelitian ini adalah penelitian yang dilakukan oleh Apriyanti Nia Dwi menggunakan metode Anime untuk meningkatkan kemampuan menulis kata kerja. Sedangkan penelitian yang peneliti lakukan yaitu dengan metode Information Gap untuk meningkatkan kemampuan dalam merubah kata kerja.

\section{KESIMPULAN}

Berdasarkan pemaparan hasil penelitian yang dilakukan pada Prodi D-IV Keperawatan Anastesiologi, maka dapat disimpulkan kendala-kendala yang dihadapi mahasiswa dalam dalam pemakaian konjugasi kata kerja bentuk masu/ mashita adalah karena mahasiswa banyak yang belum menguasai kosa kata bahasa Jepang sehingga mereka mengalami kesulitan dalam pembelajaran konjugasi. Selain itu motivasi belajar mahasiswa masih kurang. Dari faktor pengajar penyebabnya adalah kurangnya metode yang bervariasi dan alat peraga atau media yang dipergunakan pada waktu mengajarkan materi dalam konjugasi kata kerja bentuk masu/ mashita. Hasil penelitian menunjukkan bahwa dengan adanya penelitian ini, maka kendala-kendala yang dihadapi oleh mahasiswa dapat teratasi karena pada waktu mengajarkan materi tentang konjugasi kata kerja bentuk masu/ mashita dosen menggunakan metode information Gap, media kartu gambar dan kartu kosakata serta mengarahkan mahasiswa pada penggunaan media kartu gambar tersebut. Penelitian ini memiliki implikasi terhadap pentingnya mengerti jenis strategi dan kapan dan bagaimana meningkatkan kualitas perkuliahan di kelas.

\section{UCAPAN TERIMAKASIH}

Penulis dalam menyusun penelitian ini mengucapkan puji syukur kepada Tuhan Yang Maha Esa atas limpahan rahmat dan hidayah dalam Menyusun penelitian ini. Peneliti mengucapkan kepada orang tua, beserta keluarga yang telah memberikan dukungan secara moral dan materil. Terimakasih kepada Bapak/Ibu Dosen ITEKES Bali yang telah memberikan motivasi. Semoga penelitian yang disusun dapat bermanfaat bagi semua. Serta pihak yang telah memberikan dukungan dalam peneliti.

\section{DAFTAR PUSTAKA}

Afandi, M., Chamalah, E., \& Wardani, O. P. (2013). Model Dan Metode Pembelajaran Di Sekolah. In Perpustakaan Nasional Katalog Dalam Terbitan (KDT) (Vol. 392, Issue 2). 
2943 Masalah dan Solusi dalam Pemakaian Konjugasi Kata Kerja Bentuk Masu/Mashita Bahasa Jepang pada Mahasiswa - Gusti Agung Galuh Wismadewi, Putu Rusanti

DOI: https://doi.org/10.31004/edukatif.v3i5.1022

Https://Doi.Org/10.1007/S00423-006-0143-4

Apriyanti Nia Dwi. (2015). Analisis Kesalahan Dalam Penggunaan Unsur Keizoku Doushi Dengan Shunkan Doushi Pada Kalimat.

Cahyani, H., \& Setyawati, R. W. (2016). Pentingnya Peningkatan Kemampuan Pemecahan Masalah Melalui PBL Untuk Mempersiapkan Generasi Unggul Menghadapi MEA. Prisma, Prosiding Seminar Nasional Matematika, 151-160.

Fay, D. L. (1967). Faktor Yang Mempengarui Keberhasilan Peserta Didik Dalam Pembelajaran Bahasa Inggris. Angewandte Chemie International Edition, 6(11), 951-952., 105-124.

Hade, L., \& Aswirna, P. (2019). Pengembangan Media Pembelajaran Fisika Menggunakan Corel Video Studio Pro X 7 Pada Materi Teori Kinetik Gas. Natural Science Journal, 5 Nnomor 1(Pendidikan), 740753.

Jannah, A. N., Sumarlam, \& Purnanto, D. (2019). Verba Bantu ( Hojo-Doushi ) Te Iru Sebagai Penanda Aspektualitas. 79-87.

Lailatul, J. F. (2017). Hasil Belajar Berbicara Bahasa Jerman Melalui Penerapan Teknik IGA (Information Gap Activities) Siswa Kelas Xi Ips-2 Sma Negeri 3 Kediri. VI, 1-14.

Lusiana Evi. (2009). Buku Pelajaran Bahasa Jepang (Pertama).

Lusiana Evi. (2017). Nihongo Kirakira (Sawitri Tetriana (Ed.)).

Priyayi, D. F., Keliat, N. R., \& Hastuti, S. P. (2018). Masalah Dalam Pembelajaran Menurut Perspektif Guru Biologi Sekolah Menengah Atas (Sma) Di Salatiga Dan Kabupaten Semarang. Didaktika Biologi: Jurnal Penelitian Pendidikan Biologi, 2(2), 85-92.

Riska, F. (2015). Analisis Kesalahan Siswa Dalam Mengubah Masukei Menjadi Takei Di SMA Kesatrian 1 Riska. 4(1), 10-13.

Risyandi, S., Utamie, R., \& Sutjiati, N. (2017). Penerapan Penggunaan Media Anime Terhadap Mengandung Kata Kerja Bahasa Jepang ( Studi Kasus Pada Mahasiswa Tingkat II Departemen Pendidikan Bahasa Jepang Universitas Pendidikan Indonesia Tahun Ajaran 2016 / 2017 ). 116-120.

Rosliana, L. (2014). Verba Dalam Kalimat Pasif Bahasa Jepang. Izumi, 3(1), 50. Https://Doi.Org/10.14710/Izumi.3.1.50-53

Sari, M. I. (2020). Penerapan IGA (Information Gap Activities) Dalam Meningkatkan Kemampuan Berbicara Siswa Kelas 9 Smp-It Insan Cendekia Boarding School Payakumbuh. 2017(1), 1-9. IGA (Information Gap Activities), Speaking Ability\%0apendahuluan

Sari, N. I., \& Septiani, E. (2020). Meningkatkan Kemampuan Membaca Efektif Dan Menulis Kreatif Pada Siswa Sma Di Jakarta. Jurnal Terapan Abdimas, 5(2), 149. Https://Doi.Org/10.25273/Jta.V5i2.5568

Shidiq, U., \& Choiri, M. (2019). Metode Penelitian Kualitatif Di Bidang Pendidikan. In Journal Of Chemical Information And Modeling (Vol. 53, Issue 9). Http://Repository.Iainponorogo.Ac.Id/484/1/Metode Penelitian Kualitatif Di Bidang Pendidikan.Pdf

Sutedi, D. (2019). Dasar-Dasar Linguistik Bahasa Jepang (Keenam).

Sutikno, A. (2014). Metode Dan Model-Model Pembelajaran. 88.

Yulianti Tri. (2013). Pengaruh Penggunaan Media Pembelajaran Terhadap Hasil Belajar Siswa Pada Mata Pelajaran Ekonomi Di Sma. Journal Of Chemical Information And Modeling, 01(01), 1689-1699.

Yusuf A. (2012). Akhmad Yusuf A, 2012 Efektivitas Model Pembelajaran Bahasa Jepang Di SMA Negeri Cisarua Dengan Menggunakan Teknik Information Gap Universitas Pendidikan Indonesia | Repository.Upi.Edu. 1-14. 